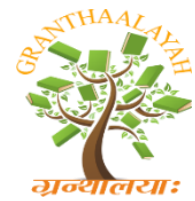

INTERNATIONAL JOURNAL OF RESEARCH GRANTHAALAYAH A knowledge Repository

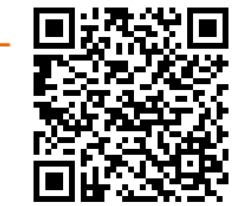

Social

\title{
RACIAL DISCRIMINATION IN JAMAICA KINCAID'S THE AUTOBIOGRAPHY OF MY MOTHER
}

\author{
Dr. T. Deivasigamani ${ }^{* 1}$ \\ ${ }^{* 1}$ Assistant Professor of English, Department of English, Annamalai University, India
}

DOI: https://doi.org/10.29121/granthaalayah.v4.i12SE.2016.2476

\begin{abstract}
Jamaica Kincaid is an American novelist, short-story writer, gardener, essayist, and reviewer. She has become one of Caribbean's major woman writers in recent decades. Kincaid's writings comprise exile, search for identity, and alienation. Her production strikes the reader with a balanced mixture of anger and loss. Kincaid's great variety of issues draws so many readers to her writings. Kincaid's novels reflect her desire to draw on the people, places, language, race, mother-daughter relationship, values, cultural traditions, and politics that have shaped her own life and that of African American people. In America, Racial discrimination is very common and hurts very much. During the slavery era, white people had black people as slaves in their own household. Black people have to satisfy their white masters. If the white people were not satisfied, they would try to hurt the black people. This paper "Racial Discrimination in Jamaica Kincaid's The Autobiography of My Mother" focuses on how race plays a pivotal role in Africans literature and their day today life and how blacks suffered for their survival. It also reveals how Kincaid's The Autobiography of My Mother illuminates black American experiences in the contemporary American society from various perspectives. It also shows how black women have been exploited in a white dominated male chauvinistic society. In the face of enormous problems and frequent victimization, black women are shown imitating through their sense of community and social powers.
\end{abstract}

Keywords: Caribbean; Race; Cultural Traditions; Politics; Slavery; Black; White; Discrimination; Victimization.

Cite This Article: Dr. T. Deivasigamani. (2016). "RACIAL DISCRIMINATION IN JAMAICA KINCAID'S THE AUTOBIOGRAPHY OF MY MOTHER.” International Journal of Research - Granthaalayah, 4(12)SE, 29-35. https://doi.org/10.29121/granthaalayah.v4.112SE.2016.2476.

\section{Introduction}

African American literature explores the issues of freedom and equality long denied to Blacks in the United States, along with other themes such as African American culture, racism, religion, slavery, a sense of home, segregation, migration, and feminism. In America, there is a 
phenomenon where some people benefit from the colour of their skin, while others are perused for the same reason. The white establishment thrusts blacks and others minorities into an "other" category, and punishes them for their differences. This system gives white people many advantages over other groups. This racial advantage has been labeled " white privilege, " and allows whites to be complacent about racial issues because instead of being hurt they actually benefit from their race. Racial discrimination is very common and hurts very much. During the slavery era, white people had black people as slaves in their own household. Black people have to satisfy their white masters. If the white people were not satisfied, they would try to hurt the black people.

Racial issue define the relations existing between people distinguished by racial descent, particularly, when the racial defenses enter into the conscious of the individual and groups so distinguished and so determines in each case the individual's conception of himself as well as his status in the community. Most commonly racism is understood as a variety of inter group resentment or prejudice. Sometimes, racism is set apart from other sentiments or beliefs of the wider class by its emotional intensity; at other times, it is set apart by reference to hereditary, biological, and extra cultural attributes which, unlike the non-racist variants of group animosity, contains.

Jamaica Kincaid is a novelist, short-story writer, gardener, and author of numerous reviews and critical essays; she has become one of Caribbean's major woman writers in recent decades. She spent her childhood and adolescence on the island during the British colonial rule. Kincaid's works comprise exile, search for identity, and alienation. Her production strikes the reader with a balanced mixture of anger and loss. Kincaid's great variety of issues draws so many readers to her writings. Garis, Leslie a distinguished critic and black studies scholar observes:

She never feels the necessity of claiming the existence of a black world or a female sensibility. She assumes them both. I think it's a distinct departure that she's making, and I think that more and more black American writers will assume their world the way that she does. So that we can get beyond the large theme of racism and get to the deeper themes of how black people love and cry and live and die. Which, after all, is what art is all about. (42)

Kincaid's novels reflect her desire to draw on the people, places, language, race, motherdaughter relationship, values, cultural traditions, and politics that have shaped her own life and that of African American people. In doing so, she offers no solutions to problems nor does she simplify the complex realities of the past or present. Instead, out of respect for the cultural knowledge that black people bring to life and living, she uses the power and majesty of her imagination to address them and anyone interested in the stories that have created a permanent place for her among America's greatest writers. This paper "Racial Discrimination in Jamaica Kincaid's The Autobiography of My Mother" focuses on how race plays a pivotal role in Africans literature and their day today life and how blacks suffered for their survival. It also reveals how Kincaid's The Autobiography of My Mother illuminates black American experiences in the contemporary American society from various perspectives. It also shows how black women have been exploited in a white dominated male chauvinistic society. In the face of enormous problems and frequent victimization, black women are shown imitating through their 
sense of community and social powers. This study examines how Jamaica Kincaid presents the sense of black identity and how she celebrates black women and the problems of race in her novel The Autobiography of My Mother. In the process, the paper traces the evolution of Jamaica as a novelist, her delineation of the pain and suffering of black women, and how far her works are able to reflect the lives of black men and women. In the words of Carine M. Mardorossian, the writing of contemporary Caribbean women, such as Kincaid, forces readers to adopt new reading strategies which emphasize not whether but when characters are "black" or "white," and it bears witness to the fact that, to quote from Maryse Condes"[there] are no races only cultures" (30).

Kincaid's The Autobiography of My Mother focuses on the character of Xuela Claudette Richardson - a Dominican woman of mixed ethnic origin. Xuela muses on her life from the vantage point of her old ripe age and examines her relations with the colonial culture fleshed out in the person of her opportunist father - Alfred Richardson — an ex-policeman and magistrate who amassed a sizeable fortune by humiliating and robbing others. He is the embodiment of the colonial presence - a ruthless capitalist whose skin was the colour of corruption copper, gold, ore. Since Xuela lost her mother when she was born, and was abandoned by her, the orphaned and disinherited Xuela is left exposed and vulnerable to the habitual brutality of colonial life which leads to her self-destructiveness and moral deformity. She refuses to love anyone but herself and aborts every child she conceives. She eventually marries a white doctor Philip, having poisoned his first wife Moira, but doggedly refuses to reciprocate his love and treats their relationship as an occasion to settle the score with the white colonizer's race.

The Autobiography of My Mother presents a whole range of perspectives of the problem of identity formation by dramatizing the cultural construction of Xuela's and her father's subjectivity. Both of them are Creoles with hyphenated identities- - Scottish African in his case, Scottish African-Caribbean in hers. Both of them are aware of the fact that identity is not a given, that it is a matter of choice and a political stance - not physical phenotypes but behaviour, loyalties and values make a person either black or white. Alfred named by his Scottish father after Alfred the Great, gives preference to his paternal lineage and disowns his maternal African heritage. He fails to appreciate his mother Mary, who "remained to him without clear features though she must have mended his clothes, cooked his food, tended his school boy's wounds, and encouraged his ambitions [...]" (AMM 183). Her surname is unknown - she is one of the African people, and "the distinction between man and people remained important to Alfred, who was aware that the African people came off the boat as a part of the horde, already demonized, mind blank to everything but suffering," while the white man "came off the boat of his own volition, seeking to fulfil a destiny, a vision of himself in his mind's eye" (AMM 181).

In "the struggle between the hyphenated man and the horde," that takes place in Xuela's father, the hyphenated man "triumphs" (AMM 188), with the effect that the father comes to "despise all who behaved like the African people; not all who looked like them but all who behaved like them, all who were defeated, doomed, conquered, poor, diseased, head bowed down, mind numbed from cruelty" (AMM 187). Thus, the father represents a shift from biological to social determinism - for him race is a matter of social status, demeanour and worldview. Blackness is not anchored in bodily characteristics, but is determined by subaltern social position, nonrational worldview and pagan beliefs. As he relentlessly toils to raise his social standing through 
the multiplication of earthly possessions, he suppresses Obeah beliefs and practices and takes great pride in becoming a very religious person because, to his mind, social advance obliges to moral elevation. According to his daughter's contrary opinion, "the more he robbed, the more money he had, the more he went to church; it is not unheard of liking. And the richer he became the more fixed the mask on his face grew" (AMM 40-41). The metaphor of the mask was presumably borrowed by Kincaid from Frantz Fanon's seminal study "Black Skin, White Masks," which, according to some critics, must have given Kincaid an incentive to write the novel. It describes the phenomenon that Fanon called 'Negrophobia' - the collective Caribbean unconscious that equals black with ugliness, sin and immorality. In Fanon's view, black people in West Indies "internalized" or "epidermalized" the racist views of themselves, believing that "one is Negro to the degree one is wicked, sloppy, malicious, instinctual" (Fanon 192).

Therefore, Fanon contends provocatively, all the black man dreams about is to rid himself of his black identity of an inferior. The way into the white world runs along the class axis: "One is white, as one is rich, as one is beautiful, as one is intelligent" (Fanon 51-52). Therefore, the acquisition of wealth grants a black man entry into the genteel world. Alfred's rise to middle class status results in his "lactification," to use Frantz Fanon's term again, and even though he becomes an alienated mimic man, totally unable to see through his sham identity, he succeeds in deploying the bourgeois culture "as a means of stripping himself of his race" (Fanon 225). Though his appearance - his red hair, grey eyes, pale skin and elegant white clothes underscores his elevated social status, the novel makes it abundantly clear that it is his upward class mobility that defines his racial affiliation.

Alfred's social trajectory from "black" village policeman to "white" landowner and magistrate illustrates that race is a variable category contingent on other identificatory categories such as class. While the father allies himself with the myths of white civilization, education and refinement, Xuela does not subscribe to this enlightened philosophical frame. She gives preference to the forces that oppose the expansion and triumph of these myths. She chooses "savagery" and asserts:

Whatever I was told to hate I loved and loved the most. I loved the smell of the thin dirt behind my ears, the smell of my unwashed mouth, the smell that came from between my legs, the smell in the pit of my arm, the smell of my unwashed feet. Whatever was native to me, whatever I could not help and was not a moral failing I loved with the fervor of the devoted. (AMM 32-33)

Xuela believes that what white culture deems "bad" must, by definition, be "good." In this spirit she passes judgements on what constitutes physical beauty: "My nose, half flat, half not, as if painstakingly made that way, I found so beautiful that I saw in it a standard which the noses of the people I did not like failed to meet" (AMM 100). The world in which Xuela lives, ruled by the Manichean oppositions, requires that a black person, like Xuela or her father, should make political and ideological choices — they must either uproot or brandish their nativism; adopt either conformist or reactionary stand.

When Xuela chooses "the native" it is obvious that she feels affinity with the exterminated Caribs rather than with the ex-African people, who survived but lost their bearing in the modem 
world. They are pictured as zombies, half dead, half alive, "walking in a trance, no longer in their own minds" (AMM 133). Having lost their native cosmology they have been severed from their own inner imaginative life - they no longer trust that they intuitively know. Unlike them, Xuela finds herself against losing access to "the inner life of her own inventions" and ardently believes in the redoubtable influence of Obeah on everyday life. While her father considers Obeah to be "the belief of the illegitimate, the poor, the low" (AMM 18), for Xuela it is an alternative epistemological frame, through which she makes sense of the world. When on the way to school, she sees one of her classmates lured to death in the river by a jabalesse (she-devil in Caribbean folklore), she never relinquishes her faith in the realness of the event she witnessed in spite of the fact that to admit having seen such an apparition" was to say that [the black children] lived in a darkness from which [they could not be redeemed" (AMM 9). Xuela chooses that darkness and learns to"[separate] the real from unreal" (AMM 42). At night she can hear the screeches of bats or "someone who had taken fee shape of the bat/' the sound of wings of a bird or "someone who had taken the shape of a bird" (42); "the long sigh of someone on the way to eternity" (AMM 43). In light of the loss of collective memory and careful erasing of the past, which Glissant described in The Caribbean Discourse, Obeah provides Xuela with a means for the imaginative repossession of the past. As she lies in her bed at night concentrating on the sounds coming from outside, she finds herself in the "dark room of history." She states:

I could hear the sound of those who crawled on their bellies, the ones who carried the poisonous lances; and those who carried the poison in their saliva; I could hear the ones who were hunting, the ones who were hunted, the pitiful cry of the small ones who were about to be devoured, followed by the temporary satisfactionof the ones doing the devouring [...]. (AMM 43)

Xuela's steady belief in the power of Obeah - an epistemic perspective that undermines the colonizer's ontology - is a sign of her resistance, her stubborn refusal to be confined within the Western grids of knowledge. Xuela's father "whitens" himself climbing the social ladder; by contrast Xuela inverts her father's trajectory and "blackens" herself transgressing gender roles. Even though she marries way above her own class and race she does not to do it with a view to becoming a mother and a lady. She not only refuses to be a bearer of children but also uses her sexuality to subvert traditional colonial scripting of femininity. Her uninhibited eroticism taps into the stereotype of sexual wantonness of the black female body that was bequeathed by slavery, perpetuated by colonial plutocracies and enhanced by the repressive Victorian sexual mores. It contrasted the alleged black female promiscuity with the idealization of the white female body. Xuela is aware how this dynamics of differentiation operates and what purposes it serves: "a lady," according to her definition, "is combination of elaborate fabrications, a collection of externals, facial arrangements, and body parts, distortions, lies and empty effort" (AMM 159). That definition is at variance with the way Xuela perceives herself, "I was a woman and as that I had a brief definition: two breasts, a small opening between my legs, one womb, it never varies and they are always in the same place" (AMM 159).

Xuela uses her sexuality to draw a line between herself and Moira, a white English lady who is the best proof that emancipation did not erase the analogous divisions between men and people, ladies and women, on which the concept of Englishness depended, "she was a lady, I was a woman and this distinction was for her important, it allowed her to believe that I could not 
associate the ordinary - a bowel movement, a cry of ecstasy — with her, and a small act of cruelty was elevated to a rite of civilization" (AMM 158-9). Moira is presented as a sexual woman who does not share a bedroom with her husband and who looks like a man - her hair is "cropped close to her head like a man's" (AMM 156), and her femininity boils down to two little breasts likened to "two old stones" and "a broken womb" (AMM 147). She is proud of the colour of her skin - the most visible marker of racial differentiation, but Kincaid's narrative points to the futility of clinging to skin colour as a major determinant of identity. Moira undergoes posthumous epidermal permutation - her skin turns black as a result of poisoning, and eventually, as it turns out, with both Xuela and Moira being black and childless, what differentiates these two female protagonists is their contradictory attitude to sexuality. It is the exhibition of her uninhibited sexual agency that makes Xuela "black," just as Moira's impaired sexuality makes her "white."

Though Xuela's characterization fits into the stereotype of the over sexualized black woman, Kincaid deftly changes the dynamics of colonial sexual representation because in the case of Xuela the sexual encounter with the white man does not trigger her sexual exploitation. On the contrary, in her relationship with Philip, Xuela uses her sexuality to subjugate and exploit him. Although at first she assumes the role of a slave, binding his belt around her wrists, still she controls their sexual act, giving Philip directions which he obediently follows. In this way the representation of the colonial encounter with the sexual other is subverted- Philip in not the dominant subject who projects his sexual fantasies on the racial other but a sexual slave enacting Xuela's wild fantasies.

According to Gary E. Holcomb and Kimberly S. Holcomb, Xuela simulates the reversal of colonial power and dominates Philip to shift agency from the master's to the slave's body and blur the distinction between the two. Through the renunciation of maternity and her narcissistic and predatory sexuality, Xuela defies the colonial power that wants to reduce her to subaltern position. Kincaid allows Xuela to hold on to the Manichean economy of colonialist discourse and the racist and sexist stereotype of black female sexuality to show that historical contexts are also constitutive of identity. In this way Kincaid not only exposes the mechanism of colonial ideological system, its logic of interracial encounters and its categories of representation, but first and foremost, she reveals that there is a concealed power dimension that determines the workings of racial instability. Race enhances meaning through adherence to or violation of gender and sexual roles that can respectively subject or liberate an individual from colonial and patriarchal domination. Consequently, it becomes impossible for the reader to treat race, gender and sexuality as "discrete categories of analysis"(109). Judith Butler claims:

[though] there are good historical reasons for keeping 'race' and 'sexuality' and 'sexual difference as separate analytic spheres, there are also quite pressing historical reasons for asking how and where we might not only read their convergence, but the sites at which the one cannot be constituted without the other. (169)

Similarly, Xuela's father understanding of race as entwined with social position undermines the colonial and early postcolonial concept of racial identity determined by lineage, dissent or blood. His conceptualization of race as white/black binary also reinforces the Manichean system of 
white bias, but at the same time it puts emphasis on the fluctuating meaning of race which is irrevocably connected with power.

Kincaid's The Autobiography of My Mother is an important novel that addresses these issues and contributes to the delineation of socio-political and discursive texture of the Caribbean, enlarging the study of racial and social relations with a new female perspective that highlights the representational interdependence of race and sexuality. Even though Kincaid's characters are still bound by the Martichean allegory, their race is no longer literal - it is metaphorical and relational. Racial markers do not create in her novel a picture of the historically objectified Caribbean subject is defined by certain presuppositions about the commonalities of his or her character, making it impossible for the reader to approach protagonists with a set of preestablished racial meanings and stereotypes.

\section{References}

[1] Butler, J., "Gender Trouble, Feminist Theory, and Psychoanalytic Discourse." Ed. L. Nicholson, Feminism/Postmodernism. NewYork: Routledge, 1990.324-41. Print.

[2] Fanan.F. Black Skin, White Masks. Trans. Larn Markman. New York: Grove Press, 1967. Print.

[3] Garis, Leslie (1990) “Through West Indian Eyes” New York Times Magazine ( 7 Oct,1990). 42. Print.

[4] Golden, S. A. R. (2011). Strategy For Success Of Human Beings:-Time Management.

[5] Holcomb.G.E. \& K.S.HolComb." I Made Him Sadomasochism in Kincaid's The Autobiography of My Mother." Callaloo 25.3, 2002. 967-76.Print.

[6] Kincaid, Jamaica. The Autobiography of My Mother. New York: Farrar, Straus \& Giroux. 1996. Print. 